\title{
THE TINDERBOX CITY: THE INDUSTRIALISATION OF FIRE DISASTERS IN HANKOU, CHINA, 1849-1944
}

CHRIS COURTNEY

Department of History,

Durham University

Hankow was notorious throughout China as a tinderbox. Indeed, to many its name was synonymous with fire.

William Rowe ${ }^{1}$

It may even be said that the injury done to China by Kerosene is more grave than that done by opium, for although opium is indeed a poison, its action is slow, whereas with Kerosene, which is found everywhere, if it once catches fire, it spreads the more you try to put it out.

Zhang Zhidong ${ }^{2}$

\section{Introduction}

One winter evening in 1849 the Yangzi River caught fire. The conflagration broke out on a sampan moored between Hankou, Wuchang and Hanyang, the three sister cities known today as Wuhan. ${ }^{3}$ Here, the harbours were so crowded that observers often described how a 'forest of masts' seemed to stretch out to the horizon. ${ }^{4}$ This forest was now ablaze. The poet Ye Diaoyuan immortalised the disastrous scenes, describing a cacophony of gongs beaten to warn of the oncoming inferno, ash floating into the air, and water turning red in the flickering light of the flames. The fire consumed all vessels in its path, from humble cargo sampans to ornate flower boats (buachuan) - a euphemism for floating brothels. Those aboard were trapped 'like fish swimming in a cauldron', yet if they jumped into the river they faced the very probable risk of drowning. So many chose this latter option that Ye remarked

\footnotetext{
1 William T. Rowe, Hankow: Conflict and Community in a Chinese City, 1796-1895 (Stanford, CA: Stanford University Press, 1989), 158.

2 North China Herald, 24 February 1888, 211.

3 I follow Rowe by focusing mostly on Hankou—or Hankow as he wrote it at the time-but we will occasionally follow fires across the rivers to Wuchang and Hanyang.

4 For example, Gretchen Mae Fitkin, The Great River: The Story of a Voyage on the Yangtze Kiang (Shanghai, North-China Daily News, 1922), 61.
} 
ruefully that although the 'fire god' (buoshen) had committed the evil act, it was the 'water god' (shuishen) who derived the benefits. Before long the merchant guilds that owned many of the burning boats sent for their private fire brigades, who dragged a number of hand-drawn fire engines to the riverside. The conflagration was now raging with such intensity that they could do little more than wait until it had burnt itself out. The economic elite of one of the greatest commercial cities in the Qing Empire stood back and watched half a million tons of precious cargo go up in smoke. ${ }^{5}$

Conflagrations such as this were not unusual in nineteenth-century Hankou. In his masterful two-volume study of the city during this period, William Rowe described how cramped neighbourhoods built from flammable materials suffered frequent fire disasters. ${ }^{6}$ Being one of the first historians to look beyond the European or American context, Rowe's pioneering analysis gained significant influence in the historiography of fire. Extrapolating from his observations, Lionel Frost drew on game theory to suggest that the citizens of Hankou were locked in the prisoners' dilemma-individuals defected from the collective responsibility to build a fireproof community, as they calculated that it was more financially expedient to replace individual buildings lost to flames. This collective deficit was exacerbated by the government, which failed to promote the necessary civic responsibility to tackle the problem. ${ }^{7}$ Frost's analysis expanded upon earlier research conducted with Eric Jones, which had suggested that nineteenth-century cities in the United States and Europe had become substantially less fire-prone due to increases in lot sizes and the development of fire-retardant architecture-a process sometimes described as brickification. Meanwhile, the cities of 'Asia and the Islamic World' remained cramped and flammable, and thus prone to devastating conflagrations. ${ }^{8}$ This vision of global urban history was, as Cornel Zwierlein has observed, 'untroubled by postcolonial reflections'. ${ }^{9}$ Instead, it posited a universalist trajectory towards urban modernity — a kind of stage theory of hazard reduction, in which European and American standards became the global aspirational ideal, and the non-West was trapped in an earlier epoch of fire.

\footnotetext{
5 Ye Diaoyuan, Hankou zhuzhici jiaozhu, ed. Xu Mingting and Ma Changsong (Wuhan: Hubei renmin chubanshe, 1985), 190-6.

6 William T. Rowe, Hankow: Commerce and Society in a Chinese City, 1796-1889 (Stanford, CA: Stanford University Press, 1984); Rowe, Hankow: Conflict. Fires had been a major problem since the city was founded in the Ming Dynasty: see Yan Changhong, 'Dahuo shao bujin, jie hou you fuxing-Ming Qing shidai Hankou da huozai', in Wuhan zhanggu, ed. Xiao Zhihua and Yan Changhong (Wuhan: Wuhan chubanshe, 1994).

7 Lionel Frost, 'Coping in Their Own Way: Asian Cities and the Problem of Fires', Urban History 24, no. 1 (1997): 5-16, doi.org/10.1017/S0963926800012141.

8 Lionel Frost and Eric Jones, 'The Fire Gap and the Greater Durability of Nineteenth Century Cities', Planning Perspectives 4, no. 3 (1989): 333-47, doi.org/10.1080/02665438908725687.

9 Cornel Zwierlein, 'The Burning of a Modern City? Istanbul as Perceived by the Agents of the Sun Fire Office, 1865-1870', in Flammable Cities: Urban Conflagration and the Making of the Modern World, ed. Greg Bankoff, Uwe Lübken and Jordan Sand (Madison, WI: University of Wisconsin Press, 2012), 82-102.
} 
The temporal framework that underpins this theory-in which fire serves as an index to gauge societal advancement - draws upon assumptions dating back at least to the nineteenth century. Cathy Frierson has described how fire was perceived as 'stigmata of backwardness' for late imperial Russia, which seemed locked in a form of rural stagnation that Western Europe had consigned to history. ${ }^{10}$ The representation of fire as a developmental deficit assumed particular potency within colonial and treaty-port cities, where radically different urban forms butted against one another. Since the eighteenth century, foreign merchants in Canton had seen the fires that ravaged the adjoining Chinese city as a pathological feature of the local culture-ignited by a 'fatalistic' population with little regard for safety and a passion for fireworks. ${ }^{11}$ Later such assumptions were codified into European insurance practices, with foreign companies refusing to issue policies for native buildings in Hong Kong and Shanghai. ${ }^{12}$ Ironically, as Zwierlein has observed, fire-loss ratios in these cities were actually lower than those found in Europe and America. Similar prejudice surrounded the issuing of fire insurance in Istanbul, despite the fact that Muslim and European buildings actually burned in similar proportions. ${ }^{13}$ In other instances, a clash of architectural styles that seemed to demonstrate the superior safety of Western styles actually represented contending adaptations to differing risks. Greg Bankoff has described how Spanish colonists in Manila built stone houses that offered excellent protection from fire, yet during earthquakes risked crushing their occupants to death. Meanwhile their indigenous counterparts lived in fire-prone bamboo and palm huts, which would inflict relatively little damage during earthquakes. ${ }^{14}$

Such examples demonstrate that the temporality of fire disasters is far more complex than is often assumed. They suggest that Asian cities were not necessarily behind Europe and America in an inexorable march towards urban rationalisation, and reveal, instead, that varying patterns of urban development generated varying risks. This more nuanced picture is reinforced when we realise that, although there may have been a statistical decline in the incidence of urban fire in the West during the nineteenth century, the conflagrations that did occur often reached startling new magnitudes. This was due to a process we might describe as the industrialisation

\footnotetext{
10 Cathy A. Frierson, All Russia Is Burning! A Cultural History of Fire and Arson in Late Imperial Russia (Seattle, WA: University of Washington Press, 2002).

11 John M. Carroll, 'Slow Burn in China: Factories, Fear, and Fire in Canton', in Empires of Panic: Epidemics and Colonial Anxieties, ed. Robert Peckham (Hong Kong: Hong Kong University Press, 2015), 35-56, doi.org/10.5790/ hongkong/9789888208449.003.0002.

12 Cornel Zwierlein, 'Perceiving Urban Fire Regimes in Europe and China (1830 to 1870): British Fire Insurance Businesses and the Sudden Challenge of Globalisation', in Historical Disaster Experiences: Transcultural Research, ed. Gerrit Jasper Schenk (Heidelberg: Springer, 2017), 327-54, doi.org/10.1007/978-3-319-49163-9_16.

13 ibid.

14 Greg Bankoff, 'A Tale of Two Cities: The Pyro-Seismic Morphology of Nineteenth-Century Manila', in Flammable Cities, ed. Bankoff, Lübken and Sand, 170-89.
} 
of fire disasters. ${ }^{15}$ As inexperienced city dwellers found themselves awash with volatile chemicals and unfamiliar technologies were woven into the fabric of older neighbourhoods, a tremendous number of novel fire hazards were unleashed. Stephen Pyne was certainly not wrong when he described how industrialisation would eventually help to reduce urban conflagrations, creating cities in which fire was almost entirely 'embedded in machines or dispersed to power plants [and] absorbed into electrical or gas appliances that eliminated the need for open flame'. ${ }^{16}$ Yet, before this advanced domestication could be achieved, industrialising cities first had to pass through what Scott Knowles has described as a 'conflagration era', in which their neighbourhoods burned 'with a ferocity that challenged the notion of modernity itself as a sustainable urban condition'. ${ }^{17}$ In this temporal framework, frequent fires were not so much an embarrassing sign of urban immaturity, more an awkward phase experienced by cities progressing to a new material form.

This article describes what happened as Hankou entered its own conflagration era. During the early twentieth century, the cramped alleyways of the city centre gave way to spacious boulevards, meaning that before long it was quite unrecognisable from the wooden metropolis described by Rowe. Despite these changes, Hankou continued to suffer regular catastrophic fires. At first it might appear that this was a problem of local governance, with politicians failing to drag their citizens into a modern world of rational planning. This article presents an alternative explanation, arguing that local attempts at reform struggled to keep pace with a continuously evolving hazard. In this respect, the situation in Hankou closely resembled that described by Christine Meisner Rosen in Chicago, Boston and Baltimore; cities that continued to suffer the scourge of fire because 'adaptations lagged significantly behind the need for adaption'. ${ }^{18}$ Yet Hankou faced considerably greater political and economic setbacks than these American counterparts, as its period of modernisation was accompanied by frequent wars and revolutions that caused near-complete societal collapse. Meanwhile, increased integration into global markets exposed Hankou to an array of new incendiary products. Wooden alleyways were doused with kerosene and petroleum, while their inhabitants struck friction matches to light machine-rolled cigarettes.

The story of fire in modern Hankou is not one that can be understood by dissecting parochial foibles of town planning_-it was part of a broader global narrative. Whilst conflagrations thrived in cramped wooden neighbourhoods, they were sparked by phosphorus dug from distant mines and fuelled by oil shipped across the ocean.

15 Definitions of industrialisation vary, but for fire history its meaning is 'crystal clear: it refers to the burning of fossil biomass'. Stephen J. Pyne, Fire: A Brief History (Seattle, WA: University of Washington Press, 2001), 155. 16 ibid., 111.

17 Scott Gabriel Knowles, The Disaster Experts: Mastering Risk in Modern America (Philadelphia, PA: University of Pennsylvania Press, 2011), 21.

18 Christine Meisner Rosen, The Limits of Power: Great Fires and the Process of City Growth in America (Cambridge: Cambridge University Press, 1986), 5, doi.org/10.1017/CBO9780511471056. 
Ironically, the profits from such incendiary products would help to lay the economic foundations for the fireproof cities of Europe and America. This dynamic was replicated in microcosm in Hankou, where matchstick merchants and kerosene barons helped to improve fire safety by modernising the city, even as the products they peddled were causing horrific conflagrations. By examining the turbulent history of one fire-prone city, this article aims a broader critique at the tendency to treat places like Hankou as laggards on the march to rationalisation. It is not sufficient to castigate particular patterns of urban morphology for turning cities into kindling without also asking how global markets ignited and accelerated the flames. True, the fires that struck Hankou were local problems caused by overcrowding and flammable architecture. Yet the flames were also fuelled by interactions with novel commodities, markets and weapons. Stated simply, Hankou did not burn because it was failing to be modern—modernisation burned Hankou.

\section{A city of fire and water}

Fire and water have been two of nature's greatest urban planners. Each in its own way has helped to forge the contours of cities, punishing those that ignored basic environmental constraints with conflagrations or inundations. While many urban populations have had to contend with one these hazards in their histories, few have suffered both with such regularity as those living in Hankou. Though both problems may seem to stem from a common problem of poor municipal governance, in reality the dialectical relationship between fire and water was considerably more complicated. Counter-intuitive as it may seem, an abundance of water actually made Hankou more fire-prone. As a thin strip of land bordered by rivers and wetlands on all sides, the city was unable to sprawl and consequently became one of the most densely populated areas in the Qing Empire. ${ }^{19}$ Local building techniques compounded the problem of overcrowding, as the houses of Hankou were constructed mostly from timber, bamboo and reed. Rowe explains that this architectural choice was the result of the city's thriving timber market, yet Frost speculates that it may also have represented the triumph of individuated costcutting over considerations of collective well-being. ${ }^{20} \mathrm{~A}$ further explanation is that these styles represented a rational response to the problem of flooding-timber and bamboo could be replaced with relative ease if damaged by water, while reed huts (maowu or maopeng) could be relocated to high ground when rivers rose. Like those living in earthquake-prone Manila, the residents of Hankou were forced to contend with a hierarchy of hazards; by ameliorating the dominant threat of flooding they generated a secondary risk of fire.

19 Rowe, Hankow: Commerce.

20 Rowe, Hankow: Conflict, 159; Frost, 'Coping in Their Own Way'. 
The relationship between fire and water was locked into the annual rhythm of advancing and retreating rivers. Although summer posed a number of fire hazards, including lightning, it was winter that was the season of fire, being relatively dry and windy, meaning sparks would be whipped up into flames. ${ }^{21}$ Winter also marked the lull in the agricultural year, when tens of thousands of rural migrants would travel to Hankou looking for casual work. Such economic nomads built huts from wildland grasses and urban detritus, filling in the gaps in the urban landscape to create an unbroken chain of combustible material. ${ }^{22}$ Meanwhile, shrinking rivers left waterways so clogged with wooden vessels that they ceased to function as firebreaks and instead became conduits for flame. Conflagrations spreading from boat to boat or sparks drifting on the wind allowed fire to jump the rivers, spreading across the not inconsiderable distance between the three Wuhan cities. ${ }^{23}$ The season of fire finally began to abate with the coming of the spring rains. Yet, rather than heralding a period of stability, the precipitation presaged the coming of the summer floods. Thus, disasters had a distinct temporality, alternating between two seasons of risk.

Hankou residents were not passive in the face of fire. Rowe detailed the considerable efforts expended by the local elite during the course of the nineteenth century to stop the city burning. Unfortunately, the bright light of reform soon lost its lustre, as zoning practices and building codes were ignored and fire lanes became congested. ${ }^{24}$ Frost was certainly correct to assert that an absence of governmental action exacerbated these problems. This was less a general problem than a specific issue arising in the mid-nineteenth century. It is worth recalling that during this era the Qing Empire was beset by an array of domestic and international pressures. In this context, it is amazing that any form of fire prevention evolved. Yet evolve it did, the clearest example being guild-sponsored fire brigades, which replaced the military-run brigades of the eighteenth century. Private firefighting was not unusual at this time. It could be found in such diverse corners of the early modern world as the bustling Japanese city of Edo and the logging camps of the American West. ${ }^{25}$ The lithograph reproduced as Figure 1 gives some sense of how private brigades operated in the Wuhan cities. It depicts a conflagration in 1884, which destroyed the Yellow Crane Tower (Huanghe Lou) in Wuchang. Though no doubt embellished by artistic imagination, the key aspects of this image are consistent with contemporary descriptions of fires.

21 See for example 'Xiakou feizai', Shenbao, 15 February 1894; 'Ku zai Hankou huozai', Shenbao, 9 September 1910; North China Herald, 10 October 1898, 665; Yan, 'Dahuo shao bujin'. Fire has a similar seasonality in Edo: see Jordan Sand and Steven Wills, 'Governance, Arson, and Firefighting in Edo, 1600-1868', in Flammable Cities, ed. Bankoff, Lübken and Sand, 44-62.

22 Rowe, Hankow: Conflict, 159.

23 ibid. See description of the 1849 fire above. There is also a report of fire jumping the river in The Straits Times, 23 September 1887.

24 Rowe, Hankow: Conflict, 158-68.

25 Sand and Wills, 'Governance, Arson, and Firefighting'; Gregory Simon, Flame and Fortune in the American West: Urban Development, Environmental Change, and the Great Oakland Hills Fire (Oakland, CA: University of California Press, 2017), doi.org/10.1525/california/9780520292802.001.0001. 


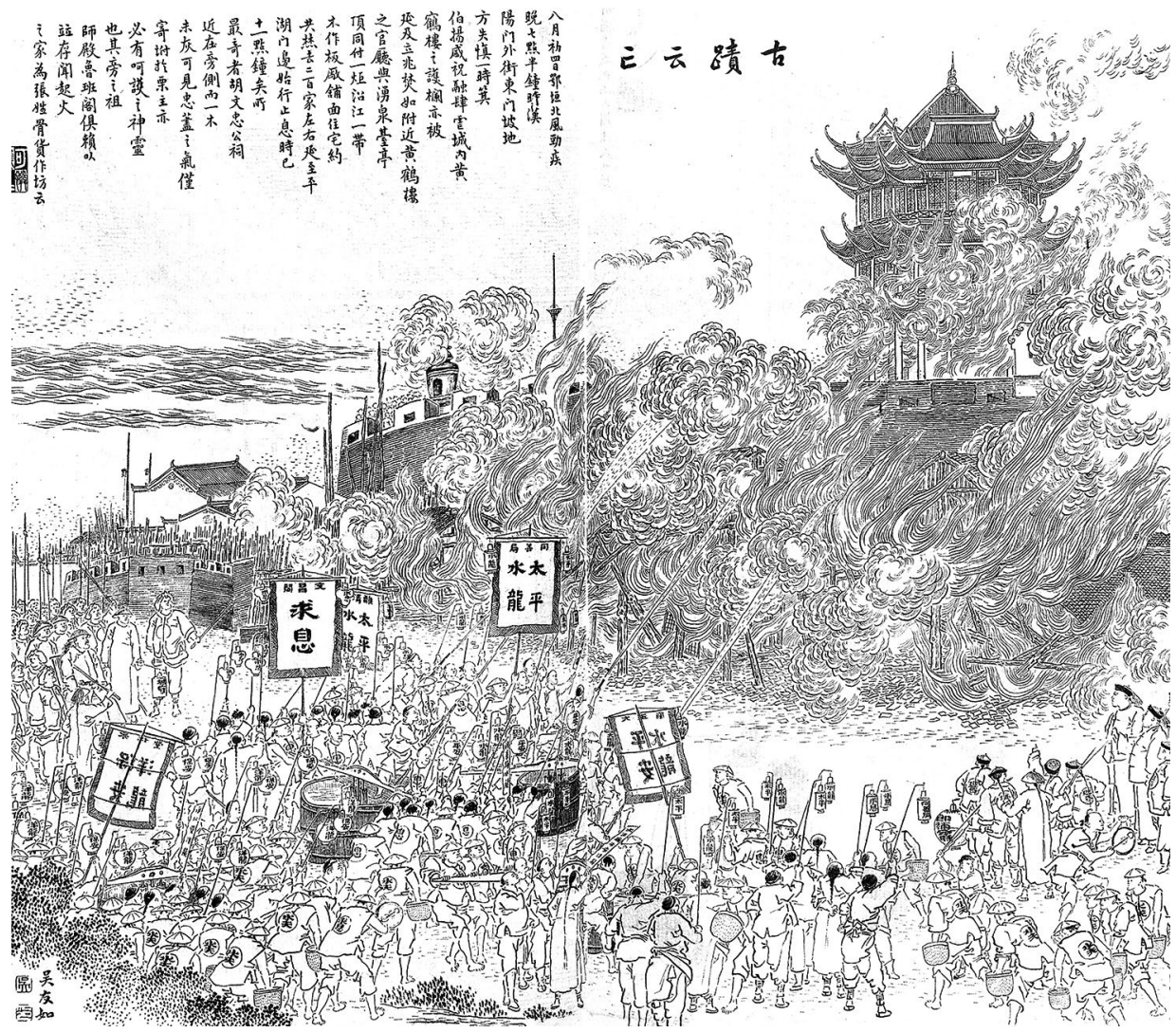

Figure 1: An Ancient Monument in Deathly Clouds (Guji Yunwang), Wu Youru, Dianshizhai Huabao.

Source: Image courtesy of the Bayerische Staatsbibliothek, Munich. ${ }^{26}$

We can gain a clear sense of the firefighting techniques and technologies available in the 1880s. In the bottom right, a figure beats a gong, which was in part a siren, announcing the passage of a fire engine, and in part an alarm system for the local population, evoking a similar note of panic to the clanging of European church bells. ${ }^{27}$ The centre is dominated by several fire brigades, each competing to tackle the blaze. Firefighters throughout the world have tended to employ two methodsusing demolition to create firebreaks and water to douse flames. ${ }^{28}$ Early Qing firefighters used both strategies, employing fire hooks to pull down houses and

26 Dianshizhai Huabao, ji ji, yi (Shanghai, 1884-89) 6: 43. L.sin K 175 1/10. Bayerische Staatsbibliothek, Munich, daten.digitale-sammlungen.de/bsb00075644/image_154, accessed 1 June 2018. Dianshizhai Huabao was a popular Shanghai pictorial. For a discussion of this particular image see also Li Qingnan, 'Jiushi Wuhan huozai yu minjian zijiu', Wuhan wenshi ziliao 2 (2015).

27 See, for example, 'Hankou huozai', Shenbao, 22 January 1891; 'Hankou huozai', Shenbao, 24 September 1895.

28 Adrian Tinniswood, By Permission of Heaven: The Story of the Great Fire of London (New York: Riverhead Books, 2004). 
throwing water from buckets. In the late eighteenth century, firefighters began to employ hand-drawn fire engines known as 'water dragons' (shuilong), which were large tanks on wheels from which jets of water were shot using hand-operated piston pumps. Later, many fire brigades began importing lighter American models, which perhaps explains why one of the engines depicted in Figure 1 has a banner reading 'foreign dragon' (yanglong). Though a valuable addition to the firefighting arsenal, fire dragons were poorly suited to the narrow alleyways of Hankou, especially when numerous private brigades were vying to be first on the scene of the fire. ${ }^{29}$

Figure 1 also gives us a sense of the institutional approach to fire in the 1880s. On the left we can see that, in addition to firefighters, a number of soldiers have been posted brandishing spears, no doubt as a precautionary measure against looting, while on the right we see a group of notables sporting distinctive hats. The centre of the lithograph is dominated by firefighting crews, each with a prominent banner revealing their name and institutional affiliation. We can see, for example, that the Praying for Peace (Qiu Xi) brigade was sent from the God of Literature Pavilion (Wenchang Ge), while the Great King Temple (Dawang Miao) had sent the Peaceful Water Dragon (Ping'an Shuilong). ${ }^{30}$ Such banners, and the accompanying characters that adorned the clothing of brigade members, helped firefighters to identify their institution amidst the confused scenes of a disaster. The missionary W. Arthur Cornaby, who witnessed similar scenes in Hanyang two decades later, suggested that these banners had a religious as well as a practical function. They were designed to 'label the merit' of the particular benevolent institution that had sponsored the brigade, to ensure that the good deed of extinguishing a fire was not 'reckoned to the wrong account in the world of the unseen'. ${ }^{31}$ Though the text accompanying Figure 1 is silent on this particular religious issue, it does describe how locals trawling through the ashes of the Yellow Crane Tower fire were astonished to discover that several shrines had remained intact. They attributed this miraculous survival to the spiritual efficacy of their protective deities (shenling), such as the carpenter god Lu Ban.

Fire was not merely a practical problem, it would seem, but also a spiritual one. ${ }^{32}$ The alleyways of Hankou teemed with a vast array of numinous forces, including hungry ghosts ('egui) and firebirds (buoniao), which could either prevent or cause

29 Rowe, Hankow: Conflict, 164. These various techniques can be observed on display in a permanent exhibition 'Chengshi daohuozhe', Shanghai Xiaofang Bowuguan, Shanghai. I am grateful to Isobel Courtney for drawing my attention to the British comparison.

30 Benevolent halls and temples offered numerous forms of support to fire brigades, their deities providing spiritual protection, their patrons offering financial support, and their buildings serving as rallying points and storage facilities. Shuk-wah Poon, Negotiating Religion in Modern China: State and Common People in Guangzhou, 1900-1937 (Hong Kong: Chinese University of Hong Kong, 2011), 22-3.

31 W. Arthur Cornaby, 'Morning Walks Around Hanyang, 3', The East of Asia Magazine (1904): 232-7.

32 I would like to thank Desmond Sham who was generous with his time discussing various ideas in this article and who helped to illuminate Chinese religious ideas about fire in particular. 
disasters. ${ }^{33}$ If one wanted to survive, placating these forces was every bit as important as having a functioning fire service. Probably the most important incendiary spirit was the Fire God (buoshen). Anxiety about this potentially malevolent figure was so potent that some would refuse to admit people who had recently suffered a fire into their homes in case his influence still lingered. ${ }^{34}$ This fear inspired citizens of Hankou to erect a special Fire God Temple (Huoshen Miao), which was, ironically, consumed by flames in the late eighteenth century. Temples were large wooden buildings stuffed with people burning candles and incense and setting off fireworks, and so were amongst the most fire-prone buildings in Hankou. Nevertheless, the fate of the Fire God Temple proved sufficiently ignominious to dissuade locals from its reconstruction. ${ }^{35}$

In addition to praying to the deities, urban citizens also employed fengshui to determine the geomantic causes of fire. One famous example occurred in the eighteenth century, when a theory arose suggesting that excessive quarrying of a mountain to the north of Hankou had exposed a 'deposit of fire' (buoku), which was now flowing directly into the city, causing frequent conflagrations. ${ }^{36}$ Fengshui seems to have fallen out of favour with the educated elite by the early twentieth century, as a local history written by the garrison commander Xu Huandou in the 1910s ridiculed those who believed that fires could be caused by the cutting of 'energy pulses' (qimai) in the landscape. ${ }^{37}$ For others, however, geomancy and religion continued to provide a meaningful explanation for conflagrations, even as new materials and markets were changing the very nature of fire.

\section{Foreign fire}

The Qing Empire lost the Second Opium War in 1860. Soon after, the British sent one of the era's most notorious arsonists to open Hankou as a treaty port. Having burned the Summer Palace in Beijing, Lord Elgin had dealt the Qing Government a humiliating blow, which remains seared in popular memory in China to this day. On his arrival in middle Yangzi, he discovered the Wuhan cities in ashes. On this occasion, the authors of destruction were the retreating forces of the Taiping Heavenly Kingdom, which had been engaged in repeated waves of invasion

\footnotetext{
33 Cornaby, 'Morning Walks', 160. The Ming naturalist Li Shizhen described firebirds, bats and rats, and something called 'devil phosphorescence' (guilin). Carla Nappi, The Monkey and the Inkpot: Natural History and its Transformations in Early Modern China (Cambridge, MA: Harvard University Press, 2009), 74-5, doi.org/ $10.4159 / 9780674054356$.

34 W. Arthur Cornaby, A String of Chinese Peach-Stones (London: C. H. Kelly, 1895), 333.

35 Dating from the seventeenth century, this seems to have later morphed into the Temple of the Four Officials (Si Guan Dian). Liu Fudao. Tianxia diyi jie: Wuhan Hanzheng jie (Wuhan: Chongwen shu ju, 2007), 180; Ye, Hankou zhuzhici, 42.

36 Fan Kai, Hankou congtan (Wuhan: Hubei renmin chubanshe, 1990 [1822]), 61.

$37 \mathrm{Xu}$ Huandou, Hankou xiaozhi (Wuhan: Aiguo tushu gongsi, 1915).
} 
and counter-invasion against the Qing forces in the city since the early $1850 \mathrm{s.}^{38}$ It was in this vastly depleted port city that the British concession was established in the early 1860s, followed in 1895 by German, Russian, French and Japanese concessions. Having long dreamed of exploiting this legendary inland entrepôt, the foreigners who made their homes in these concessions were, for the first few decades at least, frustrated by their inability to break into the Hankou market. ${ }^{39}$ Where foreign merchants failed, however, foreign merchandise thrived. The arrival of novel products would revolutionise life in Hankou, and also transform the way the city burned.

The first great incendiary import was kerosene. The burning of mineral oils was not new to China, where people had used natural deposits for at least 3,000 years. ${ }^{40}$ Yet this new industrially produced hydrocarbon fuel, first refined from coal oil by the Canadian geologist Abraham Gesner in 1846, burned with less smoke and was several times brighter than vegetable oils used for illumination. It was improved even further when petroleum replaced coal as the base material over the next decade. ${ }^{41}$ Nowadays, we tend to think of electricity as the great illumination technology of the modern world, yet the spectacular rise of kerosene was equally revolutionary. Despite some thwarted attempts to create a native oil industry, with foreign companies prospecting in Shaanxi for example, until 1949 almost all kerosene and petroleum was imported, mostly from the United States. Standard Oil enjoyed a virtual monopoly on the trade until the 1890 s, thanks in large part to the canny marketing of Ye Chengzhong, a distributor who used an empire-wide network of Ningbo merchants. The monopoly was finally broken when rival companies undercut Standard by developing cheaper bulk distribution. Still, the profits that the corporation derived from their Chinese enterprise remained phenomenal. They exported 830,000 gallons of kerosene to the Qing Empire in 1874; by 1920, their annual exports had reached 188,800,000 gallons. Little wonder that locals described kerosene as 'foreign oil' (yangyou). ${ }^{42}$

38 James Bruce, Earl of Elgin, Letters and Journals of James, Eighth Earl of Elgin (London: John Murray, 1872); William T. Rowe, Crimson Rain: Seven Centuries of Violence in a Chinese County (Stanford, CA: Stanford University Press, 2007), 199-200.

39 Isabella Bird, The Yangtze Valley and Beyond (New York: G. P. Putnam, 1900); Rowe, Hankow: Commerce. 40 Lianyong Feng, Yan Hu, Charles A. S. Hall and Jianliang Wang, The Chinese Oil Industry: History and Future (New York: Springer, 2013), 1-2, doi.org/10.1007/978-1-4419-9410-3; Lu Hanchao, 'Out of the Ordinary: Implications of Material Culture and Daily Life in China', in Everyday Modernity in China, ed. Madeleine Yue Dong and Joshua Goldstein (Seattle, WA: University of Washington Press, 2006), 30.

41 T. J. Murray, 'Dr Abraham Gesner: The Father of the Petroleum Industry', Journal of the Royal Society of Medicine 86, no. 1 (1993): 43-4. Around the same time, James Young invented a similar kind of mineral oil called paraffin, the generic name still used in the United Kingdom. John Butt, James 'Paraffin' Young: Founder of the Mineral Oil Industry (Edinburgh: Scotland's Cultural Heritage, 1983).

42 Sherman Cochran, Encountering Chinese Networks: Western, Japanese, and Chinese Corporations in China, 1880-1937 (Berkeley, CA: University of California Press, 2001), 23, 28. Kerosene is most commonly described in Chinese sources as coal oil (meiyou) or sometimes lamp oil (dengyou). 
The inexorable rise of kerosene was bolstered by the near-simultaneous arrival of another great innovation-the friction match. Again, this product was not entirely novel, as 1,000 years earlier people had impregnated pinewood sticks with sulphur to create 'light-bringing slaves' (yin guang nu). ${ }^{43}$ Despite this pioneering invention, flint and steel remained the dominant form of ignition until the nineteenth century, when the friction match, invented by the British chemist John Walker, arrived in the Qing Empire. ${ }^{44}$ Once again, Ye Chengzhong's Ningbo network played a crucial role in disseminating this new technology, establishing a string of match factories in large cities. The Hankou branch opened in 1897, under the management of Song Weichen. By 1908, it was producing half a million boxes every day. ${ }^{45}$ The poet Luo Han described how this 'foreign fire' (yanghuo) had led Hankou residents to abandon the ancient practice of passing embers from one stove to another. ${ }^{46}$ Convenience came at a heavy cost. Match factories employed women and children in horrifying conditions for little pay. Unlike much of the world, which converted to safer red phosphorus by the early twentieth century, Chinese match manufacturers continued to use cheaper white phosphorus, a chemical that caused poisoning and was liable to spontaneously combust. ${ }^{47}$ Cost-cutting helped to make merchantindustrialists such as Ye and Song vast fortunes, whilst transforming matches into 'the one artefact so cheap that people might freely ask a stranger for one', as Stephen Pyne has observed. ${ }^{48}$ Most people were either unaware of or unconcerned about the inherent abuses of the match industry, as foreign fire and foreign oil were allowing them to illuminate their homes better than ever before.

The price for light was fire. In last two decades of the late nineteenth century, kerosene became the major culprit for conflagrations in Hankou. It was not the first flammable product that locals had encountered. Products such as tung oil, raw cotton and gunpowder were known to cause dreadful infernos, yet few people kept large quantities of these materials in their homes. ${ }^{49}$ Strong alcohol was more widespread, and could cause fires, particularly when stockpiled in wine shops. ${ }^{50}$

43 Joseph Needham, Christian Daniels and Nicholas K. Menzies, Science and Civilisation in China, vol. VI: Biology and Biological Technology, part 3: Agro-Industries and Forestry (Cambridge: Cambridge University Press, 1996), 70 .

44 Stephen J. Pyne, Vestal Fire: An Environmental History, Told through Fire, of Europe and Europe's Encounter with the World (Seattle, WA: University of Washington Press, 1997), 48-9.

45 Ding Sheng, 'Hanzhen jujia-Song Weichen', Wuhan wenshi ziliao, no. 12 (2005): 7-10; Arnold Wright, Twentieth Century Impressions of Hong-kong, Shanghai, and Other Treaty Ports of China (London: Lloyd's Greater Britain Publishing Company, 1908), 695.

46 Luo Han, Minchu Hankou zhuzhici jinzhu, ed. Xu Mingting (Beijing: Zhongguo dang'an chubanshe, 2001), 67-8.

47 Dorothy Johnson Orchard, 'Man-Power in China I', Political Science Quarterly 50, no. 4 (1935): 561-83, doi.org/10.2307/2144002.

48 Pyne, Vestal Fire, 48.

49 For an example of a gunpowder fire, see 'Huoyao feizai', Dianshizhai Huabao 14, no. 88 (Shanghai, 1898). On the dangers of raw cotton, see 'Bye-Laws of the Special District of Hankow, 1925'. FO 228/3187. The National Archives (TNA), London.

50 See, for example, 'Pojiu miehuo', Dianshizhai Huabao 21, no. 19 (Shanghai, 1898). 
Yet even the strongest of spirits was hardly as volatile as kerosene, which combined flammability with ubiquity. Worse still, kerosene was burned in lamps that were often faulty and, even if not, could easily be spilled. Due to this incendiary mix, from the 1880s kerosene features more than any other product in reports of fires in Hankou. Though most involved lamps being knocked over, some had more colourful origins. In the summer of 1890, a devout Buddhist set fire to her mosquito net while trying to expel lice from her bed and ended up burning her house down. ${ }^{51}$ In another instance, two apprentices in a medicine shop knocked over a lamp while fighting, causing an inferno that destroyed five or six of the adjacent buildings. ${ }^{52}$ One of the worst accidents occurred in 1887 when an impatient chef poured kerosene onto his cooking fire, causing a blaze that would eventually burn 2,000 sampans and kill thousands. ${ }^{53}$ The oil fire problem was not limited to Hankou or even the Qing Empire. The Great Chicago Fire of 1871, an infamous disaster that burned $\$ 125,000$ worth of property every minute for 27 hours, was rumoured to have been started by a cow kicking over a kerosene lamp. ${ }^{54}$ In the United Kingdom, the problem with kerosene-or paraffin as it is known locally-became so acute that parliament debated how best to regulate the fuel. The oil industry responded with a pamphlet entitled The Moloch of Paraffin, which sought to lay the blame on faulty lamps. ${ }^{55}$ Far and wide, it would seem, the revolutionary fuel that had lit the world, had also lit the world on fire.

The sharp increase in fires prompted the great Qing statesman Zhang Zhidong, then serving as governor of Guangdong and Guangxi, to offer the scathing denunciation of kerosene that is quoted as one of the epigrams for this article. ${ }^{56}$ The suggestion that this foreign oil might be more dangerous than opium was more than a little hyperbolic_and almost certainly designed for political effect. Yet Zhang cited substantial evidence to corroborate his claim, including a fire in a Shantou paper shop, which had left 400 families homeless, and a steamship fire caused by an exploding lamp, which had left the Pearl River choking with corpses. During the winter of 1887 , he claimed, not a single day had passed without a fire in Guangdong, 90 per cent being attributable to kerosene. Zhang had an ulterior motive, as he wanted to protect the native trade in illuminating oils made from peanuts, rapeseed and soybeans. ${ }^{57}$ He was also using America's most lucrative export as leverage to reassert Qing sovereignty over trade. Drawing a comparison with the 1881 Chinese Exclusion Act, he reasoned that if the United States was able to limit Chinese immigration to protect its own population, then surely the Qing Empire

51 'Hankou huozai', Shenbao,11 June 1890.

52 'Hankou huozai', Shenbao, 27 December 1888.

53 North China Herald, 17 November 1887, 303.

54 Rosen, The Limits of Power, 92.

55 Charles Marvin, The Moloch of Paraffin (London: R. Anderson, 1886).

56 Zhang's memorial was co-authored with the governor of Guangzhou and reproduced in the North China Herald, 24 February 1888, 211.

57 On traditional lamp oils, see Needham, Science and Civilisation, 6: 8. 
had the right to limit harmful imports, concluding that 'the law that nations have a right to protect their own interests and prevent injury being done their people applies to both countries, alike, if there is any justice ${ }^{58}$ Zhang never achieved the justice he sought, as kerosene imports and kerosene fires continued unabated.

Zhang was not the only official who sought to ban kerosene, with municipal governors in Shanghai and Hankou both petitioning for similar measures. ${ }^{59}$ Governors objected to the fuel not simply because it was a foreign competitor that caused accidental fires, but also because it had become a favoured weapon of arsonists. There was nothing novel about the misuse of fire. People had been burning down buildings for as long as there had been buildings. Yet novel incendiary products took the skill out of arson. Accelerants such as kerosene and petroleum increased the speed with which devastating fires could be set, while friction matches meant that it was no longer necessary to fumble with flint or carry a flame conspicuously through the streets. Even an inept novice could now light a devastating fire in an instant. This, perhaps, goes some way to explain why a wave of incendiarism swept through Hankou from the 1880s. The unstable political environment provided the motivation, yet the industrialisation of arson provided the means. There were several different kinds of arson during this period. The criminal fraternity—described in contemporary sources as 'hooligans' (liumang) and 'brigands' (feitu)—started fires to create chaos, so they could loot property and even kidnap people. ${ }^{60}$ Meanwhile, the apocalyptic religious groups that thrived in late nineteenth-century Hankou used arson in order to further their sectarian agendas. ${ }^{61}$ One such group was reported to have been behind a spate of incendiarism that swept through Hankou in 1898, culminating in the worst conflagration since the Taiping Civil War. Several square miles of residential housing burned, and thousands were killed, including some desperate victims who drowned in mud trying to escape. ${ }^{62}$ Though nobody was brought to justice in this instance, shortly afterwards two religious arsonists were apprehended carrying spirit money doused in kerosene. Whether spirit money was chosen for convenience or for its ritual significance is unclear. The choice of kerosene was no mystery at all, as there were few fuels that could burn a city better.

\footnotetext{
58 ibid.

59 The daotai of Shanghai also tried to institute a ban: $L u$, 'Out of the Ordinary', 30. Rowe, Hankow: Conflict, $161-2$

60 See, for example, 'Fei ren zong huo', Shenbao, 30 October 1890; 'Hankou huozai', Shenbao, 22 January 1891; 'Friday Night's Fires', Hankow Daily News, 27 November 1911.

61 See Rowe, Hankow: Conflict. Materials gathered from anti-foreign sects were published in John Griffith, The Cause of the Riots in the Yangtse Valley: A 'Complete Picture Gallery' (Hankow: n.p., 1891).

62 The majority of reports attribute the fire to bandit sects: 'Hankou huozai hui zhi', Shenbao, 28 October 1898; 'Jiao fu yi yin', Shenbao, 16 November 1898; North China Herald, 31 October 1898, 814. One suggests it was an accidental kerosene fire: North China Herald, 10 October 1898, 664. There was a rumour that the foreign community had started the fire to expand their concession, vigorously denied in the North China Herald, 31 October 1898, 814. Charles Beresford claimed the fire was started by protesters who believed the lijin tax was being diverted to foreigners. Charles William Beresford, The Break-Up of China (London: Harper, 1899), 142-3.
} 
A final category of arsonist comprised urban developers who used fire to evict unwanted tenants. One of the most infamous instances of this occurred in 1909, when 3,000 thatched huts burned to the ground around Back Lake (Hou Hu) in northern Hankou, killing at least 10 occupants. This highly impoverished area was no stranger to fire, having suffered at least two in the $1890 \mathrm{~s}^{63}$ In this instance, many suspected that the landowner Liu Xinsheng had ordered the fire to clear the settlement. Known as the 'king of landlords' (dipi dawang), Liu was one of the richest men in Hankou. At the time of the disaster, he was hoping to construct a grand new neighbourhood in the north of the city. Few seemed to doubt that he would use fire to hasten this process. Before long, an angry crowd had marched to Liu's house, where they attempted to break down the door. In the ensuing chaos, a Chinese constable from the police force of the British concession was killed. ${ }^{64}$ While Liu never admitted culpability for the fire, he did pay compensation to the family of this policeman, and also to those who had lost their homes in the fire. When hard cash failed to quell the disquiet, five persistent rumour-mongers were arrested and subjected to the humiliation of being displayed in wooden cages outside the gates of Liu's opulent garden. ${ }^{65}$ This draconian treatment seems to have done the trick. When another mysterious fire tore through the Back Lake area just a few months later, no one pointed their finger at Liu. Fortunately, on this occasion there were no fatalities, yet 400 huts were destroyed, almost half of which appear to have been brothels. ${ }^{66}$

Having worked his way up from the squalid hide markets of Hankou, Liu was a hard-nosed businessman, not burdened by the scruples that had informed the behaviour of earlier generations of local merchants. ${ }^{67}$ In this respect, he typified a new breed of entrepreneurial industrialist whose uncompromising approach was galvanised by the fractious political and economic environment. Ultimately, Liu would make a far more enduring contribution to the fire safety of Hankou than his well-intentioned predecessors, who had sponsored fire brigades and tried in vain to institute moderate reforms. The spacious boulevards he built, which were lined with brick-built shopping malls and residential neighbourhoods, were far less flammable than the dense alleyways of wooden shophouses that they replaced. The centrepiece of his new development was Xinsheng Road, a grand boulevard that remains the heart of the city to this day, now renamed Jianghan Road.

63 'Hankou huozai', Shenbao, 27 October 1893; 'Hankou huozai', Shenbao, 7 March 1894.

64 'Hankou', Shenbao, 3 January 1910; 'Houhu zonghuo zishi shou si yi huo', Shenbao, 7 January 1910; North China Herald, 7 January 1910, 26.

65 'Chengbao da nao zujie anfan', Shenbao, 24 February 1910. These gardens are now Zhongshan Park.

66 'Ku zai Hankou huozai', Shenbao, 9 September 1910.

67 Zhang Yimin, 'Jiu Hankou de 'Dipi Dawang', Qi hai gou chen, April 2005; Stephen MacKinnon, Wuhan, 1938: War, Refugees, and the Making of Modern China (Berkeley, CA: University of California Press, 2008), 8-16; Rowe, Hankow: Conflict: 141, 157-8. 
The irony is that it seems that Liu may have purchased his modern flame-retardant city with fire, burning out the impoverished communities that had stood in his way. Though few were so directly culpable, the hands of other great reformers of this era were similarly blackened by fire. In 1908, the matchbox king Song Weichen constructed a large water tower, which not only made a significant contribution to public sanitation but also freed fire brigades from the arduous labour of lugging water from wells and rivers. While Song is fêted today for having constructed this great public utility, few remember how the oceans of kerosene his Ningbo network imported fuelled the flames that burned the city, with his matches igniting the spark. This selective remembrance is not peculiar to the local history of Hankou. It can be traced all the way up the food chain to Standard Oil, a company that funded the Rockefeller Foundation to conduct medical and health campaigns in China, with profits derived from selling cheap kerosene and petroleum. The point is not to castigate particular companies or merchants for moral culpability-they were not individually responsible for the structural transition to an industrialised city. Yet recognising the paradoxical role that dangerous technologies played in improving urban safety does help to complicate teleological narratives of urban rationalisation, especially when we realise that regions that enjoyed improving safety were financially linked to those that were suffering declining standards.

\section{Incendiary politics}

Of all the fires that raged in modern Hankou, none had more momentous consequences than that ignited on 9 October 1911. It was on this date that revolutionary bomb makers caused an accidental explosion in their clandestine base in the Russian concession. Little did these conspirators realise, as they dragged their unconscious comrades from the rubble, that they had ignited the spark of an accidental revolution that would soon bring down the once-mighty Qing Empire. ${ }^{68}$ As government troops investigated the fire, nervous revolutionaries in Wuchang decided to launch the famous mutiny, the opening salvo of the Xinhai Revolution. Though celebrated today as a moment of national awakening, the immediate fallout of the Wuchang Uprising had a dreadful impact upon Hankou, as the Qing forces fought fire with fire, unleashing a wave of incendiary weapons on the city. ${ }^{69}$ Since the last time that Hankou had been destroyed by weaponised fire during the Taiping Civil War, durable building materials and broadened streets had made much of the city centre far less flammable. Unfortunately, the nature of war had also evolved,

68 Michael Gasster, 'The Republican Revolutionary Movement', in The Cambridge History of China: Late Ch'ing, 1800-1911, ed. Denis Twitchett and John K. Fairbank (Cambridge: Cambridge University Press, 1980), doi.org/ 10.1017/CHOL9780521220293.010; Long Chengwu, Xinhai: Guoyun 1911 (Beijing: Zhongguo minzhu fazhi chubanshe, 2011).

69 For a discussion of the importance of war in Chinese fire history, see Zhong Maohua, 'Zhongguo huozai shi jianxi (Qin Chao-1949 nian)', Zhongguo anquan kuexue xuebao 14, no. 5 (2004). 
as the Qing Empire had imported a range of deadly incendiary weapons. ${ }^{70}$ Hence, when loyalist troops advanced upon the Wuhan cities, they were able to rain down shells manufactured by the German company Krupp. ${ }^{71}$ One of the most spectacular blazes occurred when one of these shells struck the Standard Oil depot, causing an explosion that engulfed the surrounding area with fire and plumes of black smoke. Amidst the chaos of war, looters also set fires to distract the authorities. ${ }^{72}$ Soon the streets were festooned with the decapitated heads of arsonists, hung up by their queues as a gruesome warning to others. ${ }^{73}$

In histories of the Xinhai Revolution, if the burning of Hankou is mentioned at all, then it is usually as a backdrop to the broader narrative of war and revolution-much like the flames that frame the battle pictured in Figure 2. When divorced from the grand narrative of national politics, however, this conflagration reveals much about the micro-politics of life in modern Hankou. Amongst the most striking features was the fact that a fire that reduced the Chinese city to ashes left the foreign concessions virtually unscathed. Though the inferno seemed to blaze with untameable ferocity, it would appear, therefore, that there was an element of control.

The proximate cause of this astonishing burn pattern was the desire to maintain diplomatic relations, which ensured that both loyalists and revolutionaries avoided firing upon foreign concessions. The deeper cause was the racial apartheid that foreigners had imposed upon Hankou since the 1860s, which had caused a single city to bifurcate into two distinct fire regimes. ${ }^{74}$ The concessions boasted spacious streets lined with large houses constructed from brick and stone, from which all but a select few Chinese residents were excluded by walls and barbed wire. Though often glossed as Western, the style of housing in this area was an architectural hybrid, created as foreign blueprints were redrawn to accommodate local materials, and later were reworked in the hands of local craftspeople. ${ }^{75}$ By the early 1900 s, treaty port architecture had begun to creep out of the concessions into the Chinese city, thanks to developers such as Liu Xinsheng.

70 Hans van de Ven, 'Military Mobilization in China, 1840-1949', in War in the Modern World Since 1815, ed. Jeremy Black (London: Routledge, 2003), 20-40.

71 'Untold Wealth Goes Up in Smoke', Hankow Daily News, 1 November 1911. Li Hongzhang had begun importing Krupp armaments in the 1880s. Jonathan Spence, The Search for Modern China (New York: Norton, 1990), 219.

72 'Friday Night Fires', Hankow Daily News, 27 November 1911.

73 'Looters', Hankow Daily News, 31 October and 7 November 1911.

74 The authors of a recent edited volume define the fire regime as 'the nexus of environmental conditions, including climate, topography, and natural resources, with the political system that organizes and sustains concentrated settlement'. Flammable Cities, ed. Bankoff, Lübken and Sand, 8.

75 Pan Yiting and James Campbell, 'A Study of Western Influence on Timber Supply and Carpentry in South China in the Early 20th Century', Architectural History and Theory 16, no. 2 (2017): 247-54, doi.org/10.3130/ jaabe.16.247. 


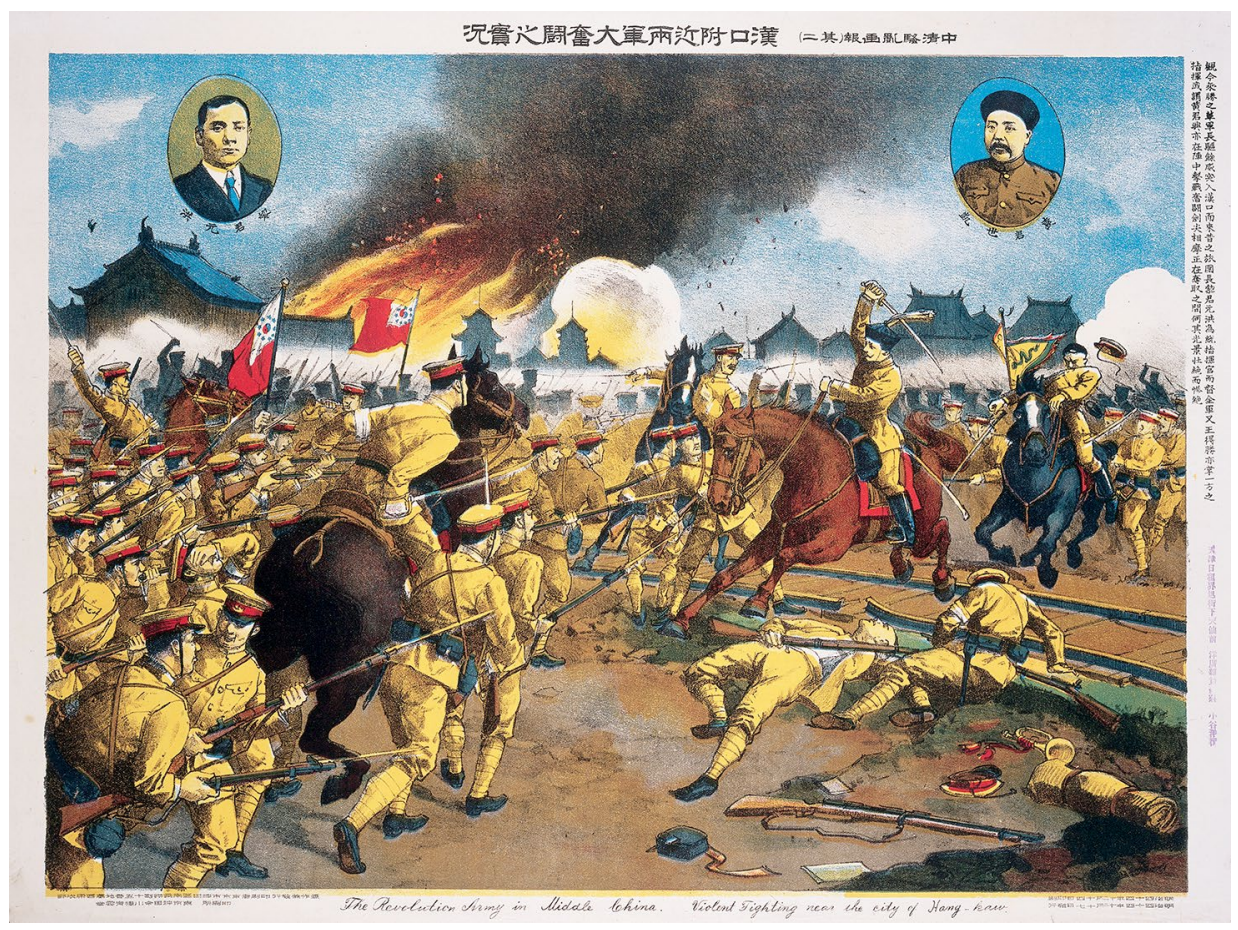

Figure 2. The Revolutionary Army in Middle China, by T. Miyano. Revolutionary and imperial soldiers fight against the backdrop of the Hankou fire.

Source: Image reproduced with the kind permission of the Wellcome Library, London.

Though the modernisation of Chinese Hankou diminished the divides separating urban forms, foreigners still retained a distinct advantage. The racial apartheid they imposed upon the city allowed them to be far more selective in how they accommodated a rapidly growing urban population. Though foreign businesses relied upon a cheap pool of migrant labour, low-waged workers were consigned to live in congested alleyways outside the concession walls. These quotidian exclusions were amplified during the 1911 fire, when the British posted soldiers to bar the concession gates, sending thousands of refugees back into the heart of the inferno. For the British journalist Edwin Dingle, the burning of Hankou seemed indicative of the callous nature of a cruel race: 'When China burns,' he inveighed, 'when she does anything that people who call themselves civilised shrink from dreaming of, she shows the world that she is the past mistress in all things that we call savage. ${ }^{76}$ Dingle does not seem to have reflected upon the savagery of his own compatriots, who barred escape routes to their fellow citizens in order to safeguard property. Instead, his sympathies were reserved for the bluejacket guards, whose 'hearts bled for the pitiful people', yet were duty-bound to prevent the menace of looting. ${ }^{77}$

76 Edwin J. Dingle, China's Revolution: 1911-1912. A Historical and Political Record of the Civil War (Shanghai: Commercial Press, 1912), 81-5.

77 ibid., 85. 

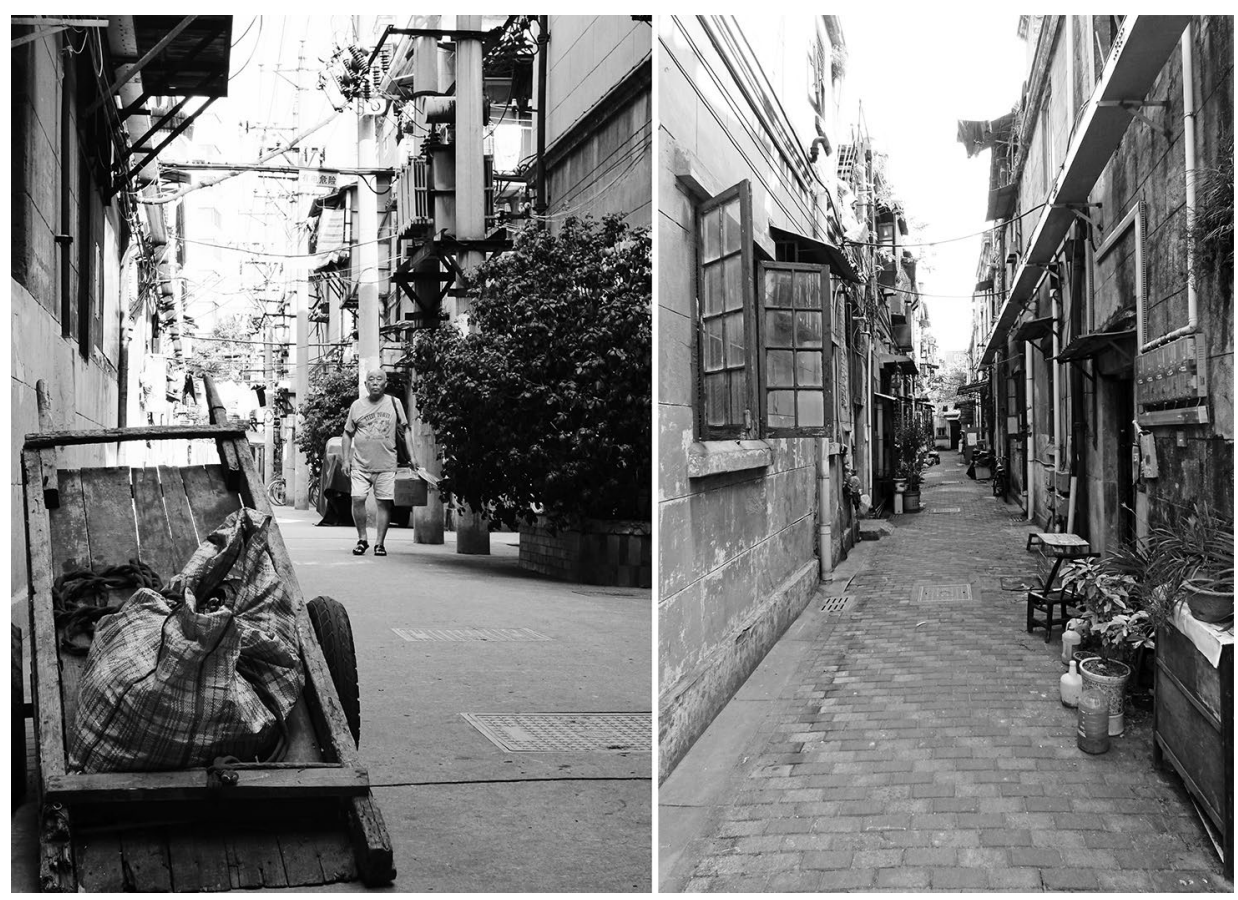

Figure 3: Hanrun Lane, built in 1937, in central Hankou.

Source: Photographs by the author, 2017.

As the new republic dawned, Hankou found itself once again in ashes. On this occasion, the disaster was of such a magnitude that it finally catalysed meaningful urban renewal. In the absence of a strong central state, once again it fell to the local business elite. Though the 1911 fire had destroyed much of Liu Xinsheng's earlier efforts, it had also provided him with a blank canvas upon which to redraw the city. The historians Sun Zhuqing and Tan Gangyi liken the post-revolutionary renaissance of Hankou to the grand rebuilding scheme in London in the wake of the 1666 fire. $^{78}$ Another comparison might be made with Chicago, reborn like a phoenix in the wake of its 1871 conflagration. With its bustling streets and vibrant trade, early twentieth-century Hankou was often described as the Chicago of the East. ${ }^{79}$ Like its great Western counterpart, it rose from its great fire stronger than before. Merchant shophouses gave way to malls, while clustered wooden neighbourhoods were replaced by terraced alleyways of brick and timber homes, built in the popular shikumen style, similar to those pictured in Figure $3 .{ }^{80}$ People still live in these alleyways today,

78 Sun Zhuqing and Tan Gangyi, 'Danhuo fen cheng yu neipan chongsheng_Lundun 1666 nian yu Hankou 1911 nian de huozai jiqi chongjian bijiao yanjiu', Xibu renju huanjing xuekan 30, no. 5 (2015): 8-15.

79 William Cronon, Nature's Metropolis: Chicago and the Great West (New York: W. W. Norton, 1991). On comparisons between Chicago and Hankou, see Walter E. Weyl, 'The Chicago of China', Harper's Monthly Magazine (October 1918): 716-24.

80 Cronon, Nature's Metropolis. 
which have been regenerated and extended numerous times in the intervening years. They are now recognised as a form of heritage architecture-a discomfiting end for an urban form once considered the height of modernity. With their creative blend of Western and Chinese architectural elements, these neighbourhoods were not only attractive but also relatively safe, having been built in a style that was, as the British concession firefighter C. O. Nicholson put it, in accordance with modern ideas ... [and thus] of greater fire-resisting value'. ${ }^{81}$

Hankou had not solved its problem with fire. Multi-building conflagrations continued to occur over the next few decades, albeit less regularly than before. One of the major reasons was that the early republic remained plagued by political instability, which frequently manifested itself in fire. In 1911, Wang Zhanyuan had been one of the military arsonists who had burned Hankou while attempting to suppress the Xinhai Revolution. Within a few years, he had risen to become one of the leading warlords in the region. When his much-beleaguered and habitually underpaid troops learned that they were to be disbanded in 1921, they ran amok in Wuchang, burning and looting. The provincial bank and at least 40 shops were reduced to ashes, while the mutinous soldiers escaped by train. They did not have long to enjoy their spoils, as Wang diverted their carriages into a siding and riddled them with machine-gun fire. ${ }^{82}$ In addition to the flames of war, residents of Hankou were still desperately vulnerable to accidental fires. The urban renewal of the $1910 \mathrm{~s}$ had had patchy results. In a sense, it had merely redrawn the fire map, making economic as well as ethnic distinctions key markers of vulnerability. The relatively wealthy residents of the city centre now enjoyed a level of protection once reserved for the concessions, yet detailed maps drawn by the British War Office in 1927 reveal that large sections of Hankou were still 'thickly populated by Chinese living mostly in huts' ${ }^{83}$ The uneven nature of urban development reflected a city rebuilt by private interests rather under the direction of a public planning authority.

It was not until the late 1920s, when the new Nanjing Government appointed Liu Wendao as mayor, that Hankou would benefit from a program of scientific city planning. His was a technocratic administration, with a penchant for collecting statistical data. Though the governance periodicals this government published were too short-lived to provide evidence of long-term trends, they do offer an insight into

81 'British Municipal Council, Hankow, Report for the Year 1925'. FO 228/3187. TNA.

82 Edward McCord, Military Force and Elite Power in the Formation of Modern China (New York: Routledge, 2014), 49-81; Fitkin, Great River, 73-6.

83 British War Office, General Geological Map of Hankow, 1946 [1927]. Reproduced in Chris Courtney, The Nature of Disaster in China: The 1931 Yangzi Flood (Cambridge: Cambridge University Press, 2018), doi.org/ $10.1017 / 9781108278362$. 
the nature of fire during the late $1920 \mathrm{~s}$ and early 1930s.${ }^{84} \mathrm{We}$ can see that perennial hazards, including heating stoves, cooking fires and altar candles, were still causing accidents, as were familiar modern culprits such kerosene and matches. The practice of bulk distribution, which importers had initiated to cut costs, meant that in addition to house fires, kerosene and petrol now caused explosive infernos at repositories and canning depots. ${ }^{85}$ By this stage, cigarettes had also become a common cause of fires. Though tobacco had been grown in China since the seventeenth century, the machine-rolled cigarettes that arrived in the late nineteenth century proved far more dangerous than traditional pipes, as the ash was not contained and they had a disposable burning tip. With 80 billion cigarettes being sold in China annually by the 1930s, there were 80 billion potential fires. ${ }^{86}$ Dozens occurred in Hankou during this period. Electricity was another novel source of fire. With the exceptions of the foreign concessions, which had received a private supply of electricity somewhat earlier, Hankou owed its electrification to a company established by the matchstick king Song Weichen in $1906 .{ }^{87}$ It is difficult to determine what impact electrification had on fire in Hankou. While the records indicate that there were a number of electrical fires during this era, we cannot discern how many kerosene fires were avoided as a result of this new technology. What is clear is that electricity did not come without risks.

Novel technologies may have brought new fire risks, but they also provided new methods of firefighting. In the eighteenth century, shops were required to own buckets to throw water over fires. By the 1920s, they could purchase fire extinguishers that used the most up-to-date chemical methods to stop flames. ${ }^{88}$ They could also call on the services of a more centralised firefighting institution, as Hankou's citywide fire brigade (Xiaofang Hui) had been established in 1910 to replace the older private brigades. ${ }^{89}$ Authority for fire prevention was not yet in government hands, and remained fractured, as foreigners insisted upon running their own volunteer brigades, bolstered by Chinese employees. Records from 1925 give some impression of the advances that had been made since the late Qing era. Hand-drawn fire dragons had been replaced by automobiles equipped with 30-metre extendable ladders, and rubber hoses that could be attached to the city's new fire hydrants. The very fact that these motorised engines could negotiate the streets of Hankou revealed the extent

84 Numerous articles including statistical and analytical information of fire can be found in two local governance periodicals. The analysis here is based on 'Wuhan shi san yuefen huozai tongji biao' Wuhan shi gongbao 1, no. 5 (1929) and the 'Huozai baogao biao' section of Xin Hankou 1, no. 7 (1929); 2, no. 1 (1930); 2, no. 5 (1930); 2, no. 6 (1930); 2, no. 8 (1931); 2, no. 10 (1931).

85 See the description of the Texaco fire below. There was also a fire in a Japanese oil godown in 1925: 'British Municipal Council, Hankow, Report'.

86 Carol Benedict, Golden-Silk Smoke: A History of Tobacco in China, 1550-2010 (Berkeley, CA: University of California Press, 2011), 10.

87 See section on the Hankow British Fire Brigade in 'British Municipal Council, Hankow, Report'.

88 Rowe, Hankow: Conflict, 164; Xin Hankou 2, no. 5 (1930).

89 Rowe, Hankow: Conflict, 167; Sun and Tan, 'Danhuo fen cheng yu neipan chongsheng'. 
to which urban planning had transformed the local fire regime. Though gongs were still beaten to raise the alarm in local communities, the concession brigade used a lingering whistle to alert the public. Meanwhile, citizens who wished to summon the fire brigade could do so by telephone. Professional firefighting techniques were accompanied by strict municipal by-laws, which stipulated the kinds of building materials that could be used, the correct manner to store inflammable materials, and prohibitions on flammable products such as fireworks and firecrackers. ${ }^{90}$ If Hankou had continued to develop as it had in the 1920s then it might have overcome its problem with fire. Unfortunately, over the next two decades it would suffer a number of blows that would inhibit its development.

The first of these occurred in 1931, when Hankou experienced a catastrophic flood, the likes of which it had not witnessed for a century. As water rushed into the streets, a number of long-banished fire hazards returned. By midsummer, hundreds of thousands of rural refugees had merged with the urban homeless in camps. These overcrowded settlements built from bamboo and thatch resembled the most fire-prone neighbourhoods of the nineteenth-century city. When one camp caught fire, a group of physicians working amongst the refugees lost everything they owned and had to tend to their patients without shoes. As well as resuscitating old risks, the flood also created new ones. Abundant water had always made Hankou more fire-prone, yet river water now flowed into a city filled with flammable chemicals, causing industrial fires in warehouses and paint shops. The most spectacular occurred when a junk crashed into a Texaco oil repository, spilling a kerosene lamp that ignited an explosive fire. Soon, barrels of oil and petroleum were seen flying several metres into the air. During the 1849 conflagration, which was described at the outset of this article, congested wooden ships seemed to set the Yangzi ablaze; in 1931, burning oil and petroleum spewing out into the river set the surface of the water on fire. ${ }^{11}$ Though these two infernos occurred in approximately the same area, in the intervening years the nature of fire had changed, together with the material epoch of the city.

\section{Fire from the skies}

We conclude our journey through the fiery history of modern Hankou by examining possibly the worst conflagration in the city's history, which also happens to be one of the most poorly documented. It occurred in the midst of the Second Sino-Japanese War (1937-45). In 1938, Wuhan, now unified as a single city, had served as the provisional capital of unoccupied China, in the period between the Nationalist retreat from Nanjing and the final evacuation to the wartime capital of

90 'Bye-Laws of the Special District of Hankow'.

91 On fires during the 1931 flood, see Courtney, Nature of Disaster, 121-2, 138-9. 
Chongqing. ${ }^{92}$ During this period, Hankou suffered sustained aerial bombardment from the Japanese, as it was catapulted into the front line of the global fight against fascism. Yet the devastation caused by this well-known assault paled in comparison to that wrought by the much less publicised American bombing of Wuhan in 1944. By this stage, the city had passed into the hands of the collaborationist regime headed by Wang Jingwei. It had become an important staging post for the Japanese military. Having failed to make a dent in the local defences with six months of highaltitude bombing, Major General Claire Chennault was finally given permission to launch a low-altitude incendiary bombing mission. On 18 December, 96 American Superfortress bombers dropped 511 tons of incendiaries on Hankou. ${ }^{93}$ Amidst the cocktail of destructive weapons deployed, this was one of the first ever uses of napalm, a terrifying new form of industrialised fire, made from a number of familiar ingredients. The base of napalm was petroleum, which was mixed with various powders to form a sticky gel that adhered to surfaces, including brick and skin. This hydrocarbon fuel, like kerosene before it, was dug from American wells and shipped in bulk to China. The detonator was made from white phosphorus, which ignites when exposed to oxygen, the same chemical reaction that is the basis of friction matches. It had taken the brightest minds of Harvard University to work out how to mix napalm in 1942, yet the actual bombs were designed by a company well-versed in the trade in fire-Standard Oil..$^{94}$

Before long the bombers flying over Hankou could barely see the city they were destroying as the incendiaries they were dropping had obscured it with smoke. This was of little concern. The Hankou raid marked a significant shift in the approach the United States took to aerial warfare. Other belligerents, both Axis and Allied, had been employing indiscriminate area bombing since early in the war. Britain had created the first firestorm in the world by dropping magnesium bombs on Hamburg in July 1943 , raising the city's temperature to $1,500^{\circ} \mathrm{F}\left(816^{\circ} \mathrm{C}\right) .{ }^{95}$ Before Hankou, however, the United States had remained steadfastly committed to precision bombing, a tactic designed to minimise civilian casualties. Now they decided to forego this moral stance, unleashing the same kind of indiscriminate incendiary bombing on the city that would soon devastate the urban population of Japan. Quite why the citizens of Wuhan, a city under foreign occupation, were granted

92 See MacKinnon, Wuhan.

93 On the raid, see Claire Lee Chennault and Robert B. Hotz, Way of a Fighter: The Memoirs of Claire Lee Chennault (New York: G. P. Putnam's Sons, 1949), 324-33; Hans van de Ven, China at War: Triumph and Tragedy in the Emergence of the New China (Cambridge, MA: Harvard University Press, 2018), 195. Robert M. Neer, Napalm: An American Biography (Cambridge, MA: Harvard University Press, 2013), 68, doi.org/10.4159/ harvard.9780674075450.

94 Neer, Napalm.

95 ibid., 62. 
less consideration than those living in Nazi Germany is not clear. ${ }^{96}$ There is much about this chapter of the war that remains mysterious, including the death toll of the raid, which some Chinese historians have claimed may have been as high as 20,000. If true, then it would mean that the Wuhan raid killed almost as many people as the infamous allied bombing of Dresden, which is now believed to have been responsible for approximately 25,000 casualties. ${ }^{97}$

The amnesia that surrounds the raid is perhaps the product of the strict censorship in place at the time, which ensured that there is little documentary evidence. More likely, it is because this episode does not fit comfortably with anyone's war narrative-neither Chinese, Japanese nor American. This most devastating of fires does, however, offer a fitting denouement for our exploration of conflagrations in modern Hankou, exemplifying as it does many of the processes that had helped to burn the city over the past century. It was ignited by a lethal mixture of industrial fuels and incendiary politics, as most fires had been since the mid-nineteenth century. It burned its way through the collective labour and capital investments of thousands of local citizens, who had attempted to build a fireproof city, only to discover that the nature of fire had evolved faster than their capacity to resist it. Finally, those who pumped the oil and mined the phosphorus at a distance were not aware of the consequences of their actions, whilst those who lit the flames seemed to forget what they had done almost instantaneously. This erasure ensured that later generations remained unaware of a shared global history of markets, materials and politics that had manifested itself in localised flames. Instead, they were left to ponder why an exotic foreign city seemed to lag so far behind the modern world when it came to fire safety. Meanwhile, the people of Hankou brushed off the ash and rebuilt their homes once again.

96 Although a compelling case could be made that this reflected some kind of racial discrimination, another explanation might be the change in leadership from General Albert Wedemeyer to General Curtis Le May. Neer, Napalm. An explanation advanced in the Chinese literature is that the raid was in revenge for the Japanese summary execution of three captured American airmen. Stephen MacKinnon, 'The US Firebombing of Wuhan, Part 2', in China in WW2, ed. Peter Harmsen, www.chinaww2.com/2015/09/16/the-us-firebombing-of-wuhan-part-2, accessed 18 February 2018.

97 Stephen R. MacKinnon has translated Chinese descriptions of the bombing but has yet to publish his own analysis in a peer-reviewed forum. MacKinnon, 'The US Firebombing of Wuhan'. On the statistics of the bombing of Dresden, see Richard Overy, The Bombing War: Europe 1939-1945 (London: Allen Lane, 2013), 476. 
This text is taken from International Review of Environmental History, Volume 4, Issue 2, 2018, edited by James Beattie, published 2018 by ANU Press, The Australian National University, Canberra, Australia.

doi.org/10.22459/IREH.04.02.2018.06 